Volume 35, Number 3

Spring/Summer, 2014

\title{
The Rural Educator
}

A Journal about Rural and Small School Issues

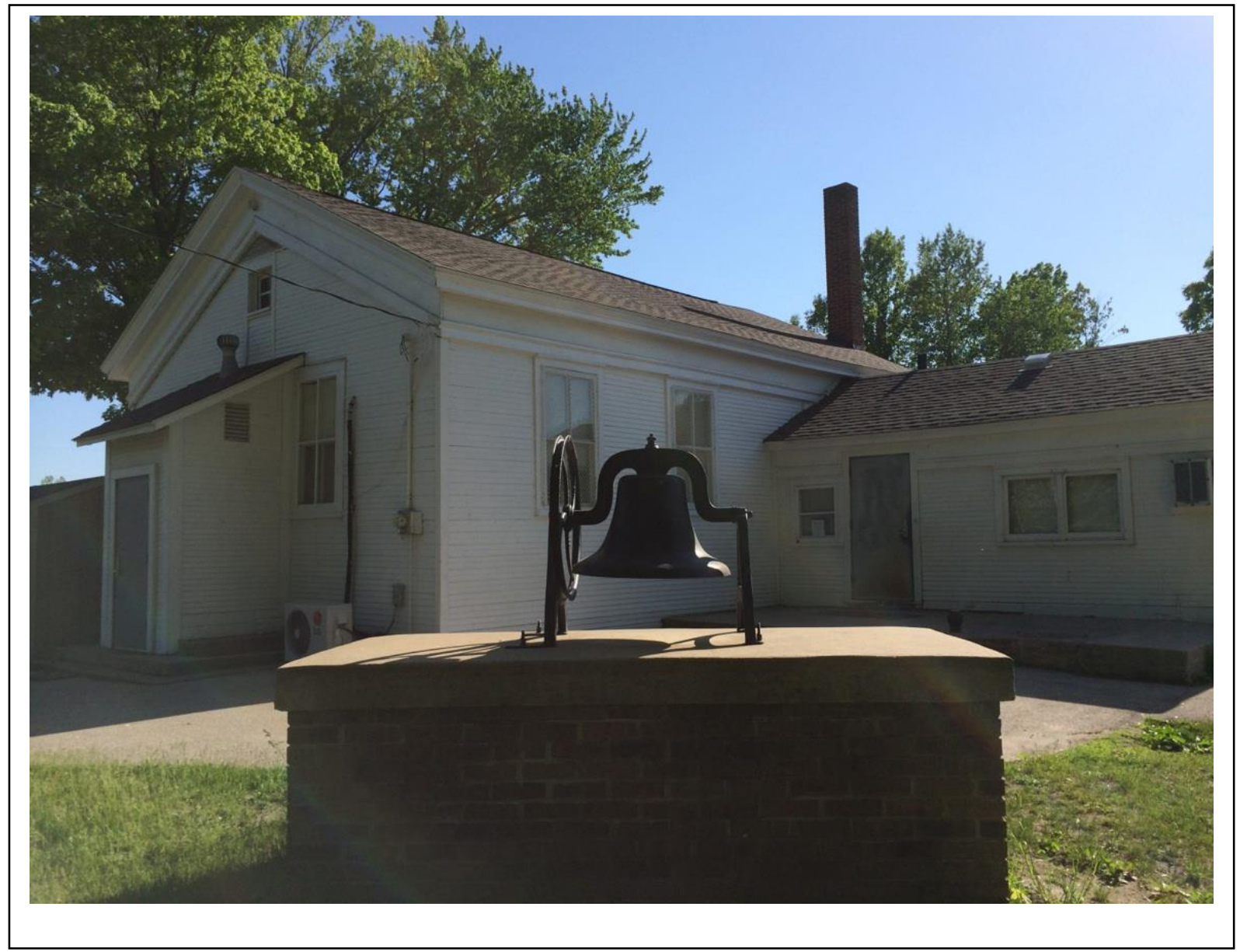

The official journal of the National Rural Education Association 
Cover Photograph submitted by Jeff Mills, Superintendent of Van Buren ISD

Bangor Township School District No. 8 (Wood School) is a one room school house that serves 27, K-8 students in Van Buren County. It was established in 1849 and the school was built in 1869 .

If you have pictures and interesting stories about a rural school that you would like to have featured on the cover of future issues of The Rural Educator, please e-mail the editor at duncanh@brandonu.ca 


\title{
The Rural Educator
}

A Journal about Rural and Small School Issues

\author{
Heather E. Duncan, Editor \\ Brandon University
}

\section{Editorial Advisory Board}

$\begin{array}{ccc}\begin{array}{c}\text { Mike Boone } \\ \text { Texas State University, San Marcos }\end{array} & \begin{array}{c}\text { Patricia L. Hardré } \\ \text { University of Oklahoma }\end{array} & \begin{array}{c}\text { Robert Newhouse } \\ \text { Kansas State University }\end{array} \\ \text { San Diego State University } & \text { Hobart Harmon } \\ \text { Education Consultant, } & \text { Susan Day Scherz } \\ \text { Scott Ferrin } & \text { Timberville, VA } & \text { Hansen School District, Idaho } \\ \text { Brigham Young University } & \text { Jody Isernhagen } \\ \text { Mary Lou Gammon } & \text { University of Nebraska - Lincoln } & \text { Sandra Watkins } \\ \text { Northern Arizona University } & & \text { Western Illinois University }\end{array}$

\section{Board of Reviewers}

\begin{tabular}{|c|c|}
\hline $\begin{array}{c}\text { Mike Arnold } \\
\text { Education Consultant }\end{array}$ & $\begin{array}{c}\text { Scott Ferrin } \\
\text { Brigham Young University }\end{array}$ \\
\hline $\begin{array}{c}\text { Andrea Beesley } \\
\text { Mid-Continent Research for } \\
\text { Education and Learning (McREL) }\end{array}$ & $\begin{array}{c}\text { Mary Susan Fishbaugh } \\
\text { Montana State University, Billings }\end{array}$ \\
\hline $\begin{array}{c}\text { Patricia Blundell } \\
\text { Chadron State College }\end{array}$ & $\begin{array}{l}\text { Connie Fulmer } \\
\text { University of Colorado at Denver }\end{array}$ \\
\hline $\begin{array}{c}\text { Michael Boone } \\
\text { Texas State University, San Marcos }\end{array}$ & $\begin{array}{c}\text { MaryLou Gammon } \\
\text { Northern Arizona University }\end{array}$ \\
\hline $\begin{array}{c}\text { Carolyn A. Brown } \\
\text { The Center for Comprehensive }\end{array}$ & $\begin{array}{c}\text { Marilyn Grady } \\
\text { University of Nebraska - Lincoln }\end{array}$ \\
\hline School Reform and Improvement & $\begin{array}{c}\text { Jean Haar } \\
\text { Minnesota State University, Mankato }\end{array}$ \\
\hline $\begin{array}{l}\text { Patrick Carlton } \\
\text { University of Nevada, Las Vegas }\end{array}$ & $\begin{array}{c}\text { Jim Hager } \\
\text { University of Nevada, Las Vegas }\end{array}$ \\
\hline $\begin{array}{c}\text { Louis F. Cicchinelli } \\
\text { Mid-Continent Research for } \\
\text { Education and Learning (McREL) }\end{array}$ & $\begin{array}{l}\text { Pat Hammer } \\
\text { Edvantia, Inc. }\end{array}$ \\
\hline $\begin{array}{c}\text { Patricia Cruzeiro } \\
\text { University of Nebraska - Kearney }\end{array}$ & $\begin{array}{c}\text { Patricia Hardré } \\
\text { University of Oklahoma }\end{array}$ \\
\hline $\begin{array}{c}\text { Kim Dadisman } \\
\text { University of North Carolina, Chapel } \\
\text { Hill }\end{array}$ & $\begin{array}{l}\text { Hobart Harmon } \\
\text { Education Consultant }\end{array}$ \\
\hline $\begin{array}{l}\text { Marilyn Dishman-Horst } \\
\text { Pittsburg State University }\end{array}$ & $\begin{array}{c}\text { Sandra Harris } \\
\text { Lamar University } \\
\text { Barbara Havlicek } \\
\text { Kansas State University }\end{array}$ \\
\hline
\end{tabular}

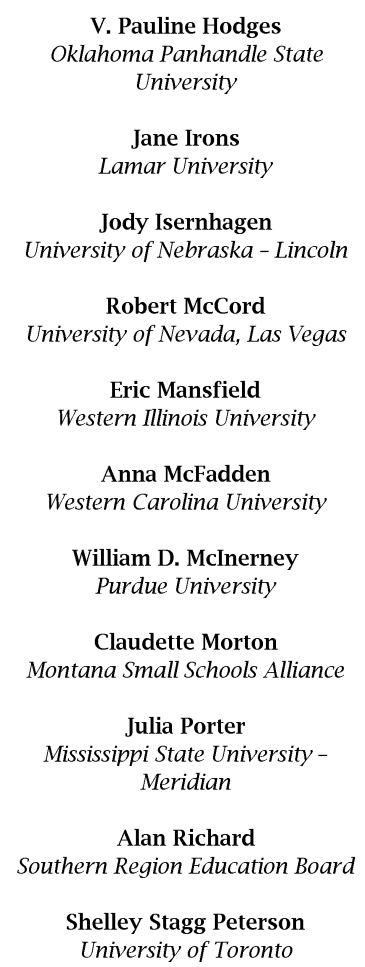

V. Pauline Hodges Oklahoma Panhandle State University

Jane Irons

Lamar University

Jody Isernhagen University of Nebraska - Lincoln

Robert McCord University of Nevada, Las Vegas

Eric Mansfield Western Illinois University

Anna McFadden Western Carolina University

William D. McInerney Purdue University

Claudette Morton Montana Small Schools Alliance Julia Porter Mississippi State University Meridian

Alan Richard Southern Region Education Board

Shelley Stagg Peterson University of Toronto

John R. Sanders $J-R-S$ Consulting

Susan Day Scherz Hansen School District, Idaho

Ingrad Smith Jackson State University

John Stellern University of Wyoming

E. Robert Stephens University of Maryland

R. Wayne Stewart Oklahoma Panhandle State University

Donna Stout Adams State College

David Sullivan University of Oklahoma

Jane Warren University of Wyoming

Regi Wieland Fort Hays State University

Sally Zepeda University of Georgia 


\section{Guidelines on Submitting Manuscripts}

The Rural Educator is a peer-reviewed journal published three times per year. The primary mission of The Rural Educator is to provide educators in rural and small schools with researchbased articles on timely issues that inform education practice or have implications for rural education policy. The journal is particularly interested in receiving manuscripts related to the impact of federal and state reform policies on rural schools, funding and finance issues related to rural schools, and issues related to specific rural populations and community development. Three types of articles are accepted for publication: General Articles, Research Briefs, and Book Reviews: All manuscripts are submitted to blind peer review without reference to name or institution. Authors will be notified of acceptance or rejection as soon as the review process is completed. Issues of The Rural Educator are published in the fall, winter, and spring of each academic year. All manuscripts should be submitted as an e-mail attachment to ruraledu@uwyo.edu

\section{General Manuscript Guidelines}

- Submit in MS Word (.doc or .docx).

- Double-spaced.

- 12 point font.

- Use American Psychological Association (APA) 6th Edition for style, citation, and reference guidelines.

- Include tables and figures within the manuscript.

- Attach a cover sheet containing the following information about the author: name, institutional affiliation, address, zip code, telephone, e-mail address, and a brief biography. This bio should be a maximum of 50 words.

- Do not include the author's name within the manuscript.

- The author will be notified of editorial changes made to the manuscript; however, the Editor reserves the right to make such changes without author approval or notification if time does not permit.

\section{Article Guidelines}

- 5000-6500 words (including references).

- Include an abstract at the beginning of the manuscript not to exceed 150 words. The abstract should briefly describe the problem or topic, method, participants, findings, and conclusions.
- Include a listing of 3-5 keywords covering the topics addressed in the manuscript for use in keyword searches.

\section{Research Brief Guidelines}

The Rural Educator will consider and publish "Research Briefs" to promote the dissemination of novel and important research information in a format that does not require extensive journal space. Studies published as Research Briefs have a very focused and explicit purpose, and applied relevance to rural settings. Research Briefs should be no longer than 2000 words, inclusive of tables, figures, and references. Research Briefs should include the following:

- Introduction - provides a brief context for the current investigation, states its focus and purpose in a clear and cogent way, and identifies one or two main research questions;

- Methods - summarizes participants, instruments, independent or intervention variables, and procedures in a succinct but clear and replicable way;

- Results - presents key results in relation to the research purpose and main question (in tables and figures, whenever appropriate);

- Discussion - identifies key findings and notes important implications in relation to the existing knowledge base, field-based application, interpretive cautions (briefly noting and describing limitations), and possibly future directions; and

- References - includes a very limited number of seminal articles that are essential for readers to understand the nature, purpose, or methods of the research.

\section{Book Review Guidelines}

A book review should give readers an engaging, informative, and critical discussion of the work (length 750-1000 words). All references should be made in-text.

duncanh@brandonu.ca

Brandon University, 270-18 ${ }^{\text {th }}$ St. Brandon, MB. R7A 6A9 


\section{The Rural Educator}

Volume 35, Number 3

Spring/Summer, 2014

Table of Contents

From the Editor iv

Impact of the English Advanced Placement (AP) Program on College Grade Point Average among Rural Appalachian Students............................................... 1 Shannon Deaton

Turnaround Reform Efforts in a Rural Context: How Community and Culture

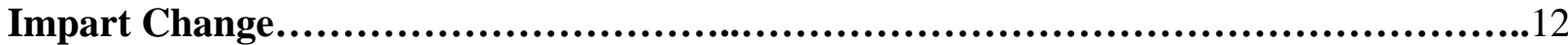
Ian Mette

A Comparison of Collaborative Practice and Teacher Leadership between Low-Performing and High-Performing Rural Kentucky High Schools.

Meagan R. Musselman, Meg A. Crittenden, Robert P. Lyons

Teachers' Beliefs about Poverty and the Impact on Learning Disabilities Identification in a Poor, Rural School District.

Renee Chandler

A nationally refereed journal about rural and small school issues sponsored by the National Rural Education Association 


\section{From the Editor}

Welcome to the Spring/Summer 2014 issue of the Rural Educator. The articles in this edition explore a diversity of interesting topics pertaining to education in rural areas. These include exploring: the impact of participation in the English Advanced placement program on rural college students' success in first year; factors that impact the success of rural school turnaround initiatives; teacher and principal relationships and actions that characterize high-performing rural schools, and the impact of teachers' assumptions about poverty on the interventions they use with students who have difficulty.

In the first article, Deaton explored the impact of the English Advanced Placement (AP) program on college success among rural Appalachian students attending four private colleges in central and eastern Kentucky. Statistical analyses revealed that the English ACT score is a better predictor of firstsemester college grade point average than the English AP score. Analyses also revealed no statistically significant difference between firstsemester college GPAs of rural Appalachian students with English AP credit and rural Appalachian students without AP credit. The study results are helpful for students, parents, administrators, and policymakers evaluating the English AP program at local high schools and colleges.

In the second article, Mette furthers research on the actions that support successful school turnaround, and also explores how and why two rural schools taking part in a Midwest State Turnaround School Project were successful in implementing school turnaround policy. Perceptions of building principals, district administrators, and regional support staff implementing turnaround policy were considered. While previous research has detailed district communication, district support of the turnaround principal, and shared leadership as important factors in successful school turnaround, . this article explores how and why the two participating rural school districts were successful implementing school turnaround and identifies the cultural and community conditions that support school turnaround in a rural setting.

In the third article, Musselman, Crittenden and Lyons report the findings of the 2011 results of 'very rural' Kentucky high schools on the Teaching, Empowering, Leading and Learning (TELL) Survey to determine whether differences exist between high and low performing rural schools across specific survey items. Rural high schools identified as high-performing demonstrated significantly different results on items related to a culture of collaboration and teacher leadership than rural high schools identified as low performing. The findings suggest that in high-performing schools, the principal and teachers support each other in their development as instructional leaders, and establish communication and collaboration skills with families and community stakeholders.

In the fourth article, Chandler examined the learning disability (LD) identification process as implemented in a high-poverty rural setting. Findings revealed the prevalence of some stereotypical beliefs among teachers regarding poverty. In addition, the traditional, Intelligence Quotient (IQ)-Achievement discrepancy model was used to identify students rather than Response to Intervention (RTI). Recommendations include providing educational activities to challenge stereotypical beliefs about people living in poverty, considering socioeconomic reform in discussions about school improvement, supporting teachers in their efforts to meet the needs of all students in their classrooms, and implementing assessment methods designed to help students receive the assistance needed as early as possible.

Finally, the editorial board now invites Research Briefs and Book Reviews as well as regular articles for publication. Full submission details can be found here. http://www.nrea.net/index.cfm?pID=7936 